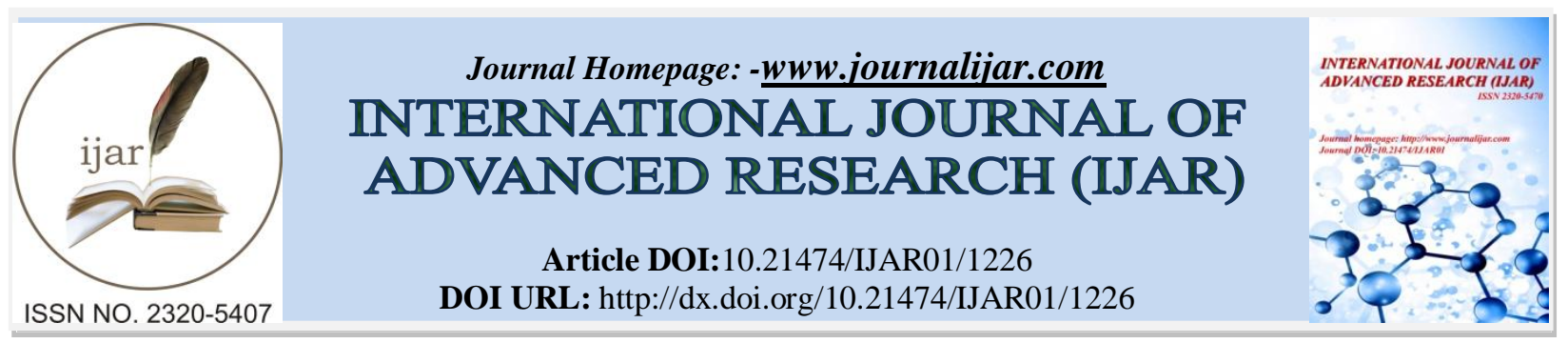

RESEARCH ARTICLE

\title{
QUANTIFICATION OF QUERCETIN, CATECHIN, AND $\beta$-SITOSTEROL, ANTIOXIDANT AND ACUTE TOXIC EFFECTS OF CalligonumcomosumL`Her DIFFERENT PARTS EXTRACT
}

\section{Kiandokht Kiani ${ }^{1,2}$, "Seyedeh Nargess Sadati Lamardi ${ }^{3}$, Seyed Nasser Ostad ${ }^{4}$, Hossein Malekafzali} Ardakani $^{5}$, Hossein Batooli ${ }^{6}$, Mansoureh Movahedin ${ }^{7}$, Reza Aflatoonian ${ }^{8}$ and Ashraf Moini ${ }^{9,2}$.

1. Ph.D. Candidate, Vali-e-Asr Reproductive Health Research Center, Tehran University of Medical Sciences, Tehran, Iran.

2. Department of Endocrinology and Female Infertility, Reproductive Biomedicine Research Center, Royan Institute for Reproductive Biomedicine, ACECR, Tehran, Iran

3. Pharm D., Ph.D.,Department of Traditional Pharmacy, School of Traditional Medicine, Tehran University of Medical Sciences, Tehran, Iran.

4. Pharm D., Ph.D.,Department of Toxicology \& Pharmacology, Faculty of Pharmacy, Tehran University of Medical Sciences, Tehran, Iran.

5. M.D., Ph.D., Epidemiology and Biostatistics Department, School of Public Health, Tehran University of Medical Sciences, Tehran, Iran.

6. Ph.D., Isfahan Research Center of Agriculture and Natural Resources, Kashan Botanical Garden, Kashan, Iran.

7. Ph.D., Anatomical Sciences Department,Faculty of Medical Sciences,TarbiatModares University, Tehran, Iran

8. M.D., Ph.D.,Department of Endocrinology and Female Infertility, Reproductive Biomedicine Research Center, Royan Institute for Reproductive Biomedicine, ACECR, Tehran, Iran

9. M.D, Department of Obstetrics \&Gynecology, Faculty of Medicine, Tehran University of Medical Sciences, Tehran, Iran.

\section{Manuscript Info}

Manuscript History

Received: 11 June 2016

Final Accepted: 15 July 2016

Published: August 2016

Key words:-

$\mathrm{DPPH}$, phenolic, catechin, quercetin, $\beta$ -

sitosterol, in vivo toxicity,

CalligonumcomosumL'Her.

\section{Abstract}

CalligonumcomosumL ${ }^{\prime}$ Her (C. comosum) belongs to the polygonaceae family and is known as Escanbil in Iran. The objective of this study was to assess quantification of phenolic antioxidants quercetin, catechin, and $\beta$-sitosterol, antioxidant, and toxic effects of ethyl acetate fraction from different parts including root, fruit, stems, aerial (leaves and flowers) and the whole parts $o f C$. comosum.HPLC with UV detection was employed for quantification of quercetin, catechin, and $\beta$-Sitosterol present in different parts of $C$. comosum. Antioxidant activity of all samples was evaluated using 2, 2-diphenyl-1-picrylhydrazyl (DPPH) method. Toxicity of extracts was assayed by brine shrimp, MTT, and animal models.HPLC analysis of quercetin showed high levels of this compound in fruits $(2 / 7 \pm 0.25 \mathrm{mg} / \mathrm{g})$ and aerial parts $(2 / 1 \pm 0.14 \mathrm{mg} / \mathrm{g})$ as well as, catechin in the plant root $(83 / 9 \pm 9.85 \mathrm{mg} / \mathrm{g})$ of $C$. comosum. Aerial parts and then the whole plant extract also containing $\beta$-sitostrol in the highest amount. Comparison of the DPPH results showed that the aerial part of the plant has more antioxidant potential. The brine shrimp lethality bioassay showed that the fruit extract with LC50 $126.8 \mu \mathrm{g} / \mathrm{mL}$ was more toxic. The results of in vivoacute toxicity evaluation showed moderately toxicity of the ethyl acetate fraction from aerial part of the C. comusom extract. These findings can help clinicians for selection the best part with lowest side effect in future clinical trials.

Copy Right, IJAR, 2016,. All rights reserved.

Corresponding Author: Seyedeh Nargess Sadati Lamardi. 


\section{Introduction:-}

Calligonumcomosum, a dominant vegetation component of sandy deserts across central Asia, is a summer-shedding woody shrub, found in desert scrub.

This species is very broadly distributed in Middle Asia, the Middle East, Iran and Saudi Arabia (Pyankov, et al. 1999, Taia and El-Etaby 2006, Dashti, et al. 2011). It belongs to the polygonaceae family and is known as Escanbil in Iran. C. comosum. The Calligonumspecies have extended in desert areas of Khozestan, Sistan and Baluchestan, Semnan, Kerman and Yazd provinces in Iran (Ranjbarfordoei, et al. 2013).

The plant extract infolklore medicine has been used for treatment of different disease such as diabetes mellitus (Masoum, et al. 2013) and for stomach ailments and curing toothache (Ghazanfar 1994). In addition, the other activities such as hypoglycemic effect (El-Hawary and Kholief 1990), anti-gastric ulcer activity (Liu, et al. 2001), anti-fumigatus, anticancer and anti-bacterial activity (Badria, et al. 2007, Alwakeel 2008, Hammami, et al. 2011, Ali, et al. 2012) have been shown in animal studies.

Antioxidant activity and its ability for ROS scavenger may have an important role in this respect.

Several antioxidative compounds have been isolated from the ethyl acetate fraction of $C$. comosummethanolic extract, such as (+)-catechin, dehydrodicatechin A, kaempferol-3-O-rhamnopyranoside, quercetin (quercetin-3-O-rhamnopyranoside), isoquercetin (quercetin-3- $O$-glucopyranoside), kaempferol-3- $O$-glucuronide and mequilianin (quercetin-3-O-glucuronide) (Badria, et al. 2007). The antioxidative activity of the $C$. comosumextract has also been demonstrated in vivo (Abdel-Sattar, et al. 2014).

A detailed knowledge of Calligonumcomosum components will lead to a correct application of its constituents for treatment of the other health problems. Furthermore it is not clear which part of Calligonum plant has more antioxidant capacity. The objective of this study is to assess the antioxidant, cytotoxic effects and quantification of catechin, quercetin and $\beta$-sitosterol of Different parts ofEscanbil (Calligonumcomosum) including root, and aerial parts (fruit, stems and flowers).

\section{Material and Methods:-}

\section{Plant Material:-}

Different parts ofEscanbil (Calligonumcomosum) including root, and aerial parts (fruit, stems and flowers) were collected from the local area of (Esfahan province), Iran at blossom time (May to June 2014). A voucher specimen was kept at Kashan Botanical Garden Herbarium, Tehran, Iran with the accession number KBGH 1101.

\section{Extract preparation:-}

The collected partswere separately dried at room temperature and in the shade for 4 weeks. After drying, each part and also whole plant were powdered with a grinder and soaked in $70 \%$ aqueous ethanol (Merck, Germany) for three days at room temperature. The excessive ethanol and water were evaporated with a rotary vacuum evaporator $(60$ rpm at $40{ }^{\circ} \mathrm{C}$ ). Totally, 5 crude extracts were obtained and stored at $4^{\circ} \mathrm{C}$ until use. The part of each 5 ethanol extracts (about 4 g.) was then further fractionated with hexane, chloroform and ethyl acetate, respectively. Ethyl acetate fraction was kept in a refrigerator for further bioactivity assay.

\section{HPLC analysis of phenolic compounds and $\beta$-Sitosterol:-}

HPLC with UV detection was employed for the identification and quantification of the phenolic antioxidants (quercetin and (+)-Catechin), and $\beta$-Sitosterol present in ethyl acetate fraction.

\section{Chemicals and reagents:-}

The catechin, quercetin and $\beta$-sitostrol (Sigma, Germany) were used as reference standards. All solvents were HPLC-grades and purchased from Merck Company.

\section{HPLC System Characteristics for quercetin assessment:-}

Analytical high-performance liquid chromatography (HPLC) separations were performed on an Agilent 1200 Series system (Agilent Technologies) consisting a G1379A degasser, G1311A quaternary pump and a G1316A column oven, Set at $20^{\circ} \mathrm{C}$, coupled to a G1315B photodiode-array, a Zorbax Eclipse plus C8 (250_4.6mm, $5 \mathrm{~mm}$ ) column 
and a detector set to scan from 190-400 nm (PDA). Elution was carried out by a mobile phase consisted of A (Phosphoric acid) and solvent B (Methanol) and the gradient profile was as follows: from 0\% $\mathrm{B}$ to $80 \% \mathrm{~B}$ in $30 \mathrm{~min}$, from $80 \% \mathrm{~B}$ to $80 \% \mathrm{~B}$ at $30-33 \mathrm{~min}$, from $80 \% \mathrm{~B}$ to $5 \% \mathrm{~B} \%$ at $33-35 \mathrm{~min}$. The detection wavelength was set at 360 $\mathrm{nm}$. The flow rate was $1 \mathrm{~mL} / \mathrm{min}$. The injection volume was $10 \mu \mathrm{L}$. The concentrations of reference substance quercetin, used for the calibration curve were $1,5,10,25$, and $50 \mathrm{ppm}$.

\section{HPLC System Characteristics for catechin assessment:-}

Analyses were performed on an Agilent 1200 Series system (Agilent Technologies) equipped with a diode array detector. HITACHI LaCHROM C18 $(5 \mu \mathrm{m}) 4.6 \mathrm{mml} \mathrm{D} \times 150 \mathrm{~mm}$ column was employed for the separation. The binary mobile phase consisted of solvents $\mathrm{A}\left(0.05 \% \mathrm{H}_{3} \mathrm{PO}_{4}, \mathrm{pH} 2.4\right)$ and $\mathrm{B}\left(\mathrm{CH}_{3} \mathrm{OH} / \mathrm{CH}_{3} \mathrm{CN}=3 / 2\right)$. The gradient elution started with $10 \% \mathrm{~B}$ and changed to $25 \% \mathrm{~B}$ in 15 minutes, then reached $60 \% \mathrm{~B}$ in 25 minutes and then changed to $10 \%$ in 40 minutes. The flow rate was $1.0 \mathrm{~mL} / \mathrm{min}$ and Injection volume was $10 \mu \mathrm{L}$. Spectral data for all peaks were recorded in $280 \mathrm{~nm}$.

The concentrations of reference substance catechin, used for the calibration curve were 25, 50, 100, $250 \mathrm{ppm}$.

\section{HPLC System Characteristics for $\beta$-sitosterol assessment:-}

Chromatographic profiles for $\beta$-sitosterol assessment of extracts were generated using a high performance liquid chromatography connected to a Smart line pump 1000 including $10 \mathrm{ml}$ pump head stainless steel and a smart line UV detector 2600 PDA (Kenauer, Germany). The separation was performed with Vertex column C18 $(250 \times 20 \mathrm{~mm}$ I.D.), Kenauer using acetonitrile (A) and water (B) as mobile phases at a flow rate of $1 \mathrm{ml} / \mathrm{min}$. The gradient program was set as follows:0-10 min: 10\% A- 90\%B, 10-30 min: 30\% A- 70\% B, 30-60 min: 50\% A- 50\% B. The injection volume was $1 \mu \mathrm{L}$. The detection wavelength was set at $271 \mathrm{~nm}$.

The concentrations of reference substance $\beta$-sitosterol, used for the calibration curve were $0.25,0.5,1 \mathrm{mg} / \mathrm{mL}$.

\section{Antioxidant activity:-}

Antioxidant determination of DPPH assay:-

The samples were evaluated for their free radical scavenging activities using 2, 2-diphenyl-1-picryl-hydrazyl (DPPH) method according to Brand Williams et al. (1995). Different concentrations of sample solutions (1 mL) in methanol were added to DPPH methanol solution $(2 \mathrm{ml}, 40 \mu \mathrm{g} / \mathrm{mL})$. After $30 \mathrm{~min}$, the absorbance was measured at $517 \mathrm{~nm}$. Percentage of radical scavenging activity of samples was calculated according to the following equation: Inhibition $\%=[(\mathrm{A} 0-\mathrm{AS}) / \mathrm{A} 0] \times 100$ that $\mathrm{A} 0$ is the absorbance of the control and AS is the absorbance of the sample. Half maximal inhibitory concentration $\left(\mathrm{IC}_{50}\right)$ values (indicate the concentration of the sample $(\mathrm{mg} / \mathrm{mL}), \mathrm{required}$ to scavenge $50 \%$ of DPPH) were calculated from the plotted graph of scavenging activity versus the concentration of extract, using linear regression analysis (Kahkeshaniet al. 2013).

\section{Cytotoxicity screening:-}

\section{Brine shrimp lethality bioassay of the extracts:-}

The brine shrimp lethality bioassay was used to study the toxicity of the extract. The brine shrimp eggs (Artemisalina) were hatched in artificial sea water $(3.5 \% \mathrm{NaCl}$ in water) and the mature shrimp or nauplii were achieved after $48 \mathrm{~h}$. For experiment, the $5 \mathrm{mg}$ of stoke solution (extract) was dissolved in dimethyl sulfoxide (DMSO) and it then was serially diluted using simulated sea water. The different concentrations $125 \mu \mathrm{g} / \mathrm{ml}, 250$ $\mu \mathrm{g} / \mathrm{ml}, 500 \mu \mathrm{g} / \mathrm{ml}, 1000 \mu \mathrm{g} / \mathrm{ml}$ were obtained. About 10-15 nauplii were transferred into each experiment vial. The number of survived nauplii was counted after $24 \mathrm{~h}$. A vial containing DMSO diluted to 5 ml normal saline was used as a control.

The mortality endpoint of this bioassay was defined as the absence of controlled forward motion during 30 second of observation. Then, the average lethality value of the brine shrimp for each concentration was calculated. An approximate linear correlation was observed when logarithm of concentration versus percentage of mortality was plotted on the graph paper and the value of the LC50 were calculated using Microsoft excel 2007.

\section{In Vitro cytotoxicity screening:-}

Cancer cell lines and culture medium:-

The colon carcinoma (HT-29), colorectal adenocarcinoma,(Caco-2), and breast ductal carcinoma, (T47D) cell lines, respectively, were maintained as exponentially growing cultures in RPMI 1640 cell culture medium (PAA, 
Pasching, Austria) supplemented with 10\% fetal bovine serum (FBS; PAA) for HT-29 cells and 15\% FBS for Caco2 and T47D cells. The Swiss mouse embryo fibroblast (NIH 3T3) cell line was kept in Dulbecco's modified Eagle's medium (DMEM; PAA) supplemented with $10 \%$ FBS. One hundred $\mathrm{IU} / \mathrm{mL}$ penicillin and $100 \mu \mathrm{g} / \mathrm{mL}$ streptomycin (Roche, Penzberg, Germany) were added to the media. All cell lines were cultured at $37^{\circ} \mathrm{C}$ in air/CO2 (95:5 v/v) atmosphere.

\section{Determination of cell viability by the MTT assay:-}

Cytotoxic activities of the ethyl acetate fraction, from Calligonumcomosum against breast ductal carcinoma (T47D), colon carcinoma (HT-29), colorectal adenocarcinoma (Caco-2), and Swiss mouse embryo fibroblast (NIH 3T3) cell lines were performed according to our previous study by the mitochondrial tetrazolium test (MTT) (khanavi et al., 2010).

\section{Acute Toxicity assay in Animal Model:- \\ Animals:-}

Thirty NMRI female (Naval Medical Research Institute) mice aged 10-16 weeks with approximate body weight of $25 \mathrm{~g}$ (obtained from the animal house of TarbiatModares University of Medical Sciences, Tehran, Iran) were used for experiments. The animals were housed in groups of five per cage under standard laboratory conditions within a temperature-controlled environment on a $12 \mathrm{~h} / 12 \mathrm{~h}$ light-dark cycle. They spent at least one week as an acclimatization period before experimentation. They had free access to water and standard pellet food. All experiments were approved by the Ethics Committee of Tehran University of Medical Sciences, Iran.The experiments were carried out according to the Organization of Economic Co-operation and Development (OECD) guideline 420 (OECD, 2001).

\section{Dose administration and estimation of the mortalities percentage:-}

The animals were allocated randomly in each group using a random number table. Five doses $(355.5,533.3,800$, $1200,1800 \mathrm{mg} / \mathrm{kg}$ ) of ethyl acetate fraction, obtained from aerial parts and fruits extract, were chosen which were given as single dose and by intraperitoneal route to five groups of mice, five mice in each group. The volume of injection was $0.2 \mathrm{cc}$ for each mouse. The first group of animals was administered with the vehicle in which the test substance was dissolved or diluted in normal saline. However, from the second group onward receives different doses of the test substance. The animals in each group received specific doses, while increment in dose progresses from group to group (starting from group 2 which received the lowest dose).

The animals were observed every hour for 8 hours and then at $20^{\text {th }}, 22$ th and 24 th hours for any toxic signs and symptoms. After 24 hours, the percentage of mortality was calculated.

\section{Second method for acute toxicity evaluation:-}

Acute toxicity determination was also performed according to chinedu method with slightly modification (Chinedu et al., 2013). Animals were divided into five groups of two animals each. Then different doses of the test substance $(50,100,200,400,800 \mathrm{mg} / \mathrm{kg})$ were administered via intra-peritoneal to the different animals. The animals were observed for 1 hours post-administration and then 10 minutes every 2 hours interval for 24 hours. The behavioral signs of toxicity and also mortality were recorded. Where mortality was recorded at a given dose in any of the stages, a confirmatory test was carried-out to actually validate that the test substance was the cause of such mortality. This test involved the administration of the dose of test substance that caused mortality (or lowest dose that caused mortality in a situation that recorded more than one mortality) to two animals. Then observation was performed for 1 hour after administration and 10 minute every 2 hours interval for 24 hours. Where at least a single animal from the two animals die, it considered as a confirmation and validation of the test result. After the test procedure, the following formula was employed in the calculation of the LD50: [LD50 $=(\mathrm{M} 0+\mathrm{M} 1) / 2]$

Where $\mathrm{M} 0=$ Highest dose of test substance that gave no mortality,

M1 = Lowest dose of test substance that gave mortality.

After LD50 estimation, the toxicity level was categorized according to code of federal regulations (Code of Federal Regulations, 2009).

Statistical analysis:-

All the results were expressed as mean \pm standard deviation (SD) and were analyzed by One-way analysis of variance (ANOVA) (Tukey, Post hoc, SPSS for windows, version 21.0). P $<0.05$ was considered as statistically significant. 


\section{Results:- \\ HPLC analysis of the extracts of $C$. comosum fractions:-}

Quantification of quercetin, catechin, and $\beta$-sitostrol in five samples of C. comosum were carried out using HPLC analysis.(Figures 1-3) According to the results exhibited in table 1, HPLC analysis of quercetin in different parts of the plant showed high levels of this antioxidant compound in fruits $(2 / 7 \pm 0.25 \mathrm{mg} / \mathrm{g})$ and aerial parts $(2 / 1 \pm 0.14$ $\mathrm{mg} / \mathrm{g})$. Analysis of catechins also represented that the highest amount of catechin existed in the plant root (83/939 \pm $9.85 \mathrm{mg} / \mathrm{g})$. As well, aerial parts $(19.66 \pm 0.03 \mathrm{mg} / \mathrm{g})$ and then the whole plant $(11.33 \pm 0.09 \mathrm{mg} / \mathrm{g})$ extract containing $\beta$-sitostrol in the highest amount.

\section{Antioxidant activity of $C$. comosum:-}

Free radical scavenging activities of different concentrations of ethyl acetate fraction from total extract of five samples from C. comosum were evaluated using 2, 2-diphenyl-1-picryl-hydrazyl (DPPH). $\mathrm{IC}_{50}$ values were shown in table 2. Comparison of the results showed that the aerial parts of C. comosum are more potent than the other samples.

According to the results of anti-oxidant and effective compounds assay of ethyl acetate fraction, we selected the aerial parts (leaves and flowers) and fruits for other experiments such as acute toxicity assessments.

\section{Brine shrimp lethality assay of ethyl acetate fraction of $C$. comosum different parts:-}

The brine shrimp lethality bioassay of ethyl acetate fraction of the samples showed that the fruit extract with LC50 $126.8 \mu \mathrm{g} / \mathrm{mL}$ was more toxic than the other samples.

\section{Determination of cell viability by the MTT assay:-}

Cytotoxic activities of the ethyl acetate fraction, from C. comosum against T47D, HT-29, Caco-2, and NIH 3 T3 cell lines were performed by the mitochondrial tetrazolium test (MTT). Results showed nontoxic effect of all samples on studied cell lines. IC50 of all samples was $>1000 \mu \mathrm{g} / \mathrm{mL}$.

\section{Clinical signs of toxicity recorded during experiment:-}

The calligonum dose of $355.5 \mathrm{mg} / \mathrm{kg}$ (ip) showed lowest side effects and low signs of toxicity. However, at the doses 1200 and $1800 \mathrm{mg} / \mathrm{kg}$, animal showed signs of toxicity during 16-24 hours post injection. The animals exhibited somnolence, weak touch response, tremor, dorsal fasciculation, weak chewing, and weakness in leg movement. The animals showed labored breathing, gasping before death.

The percentage of animals that died at each dose was then transformed to probit (Figure 4). ${ }^{[20]}$

\section{Dose-Response plot:-}

This graph shows the probabilities, ranging from 0 to 1 , and the corresponding dose. Two additional curves represent the $95 \%$ confidence interval for the dose. According to acute toxicity classification table, it can be classified as moderately toxic agent.

\section{Results of Chinedu method for toxicity:-}

During 24 hours of injection, there was death in two doses $(200,400 \mathrm{mg} / \mathrm{kg})$. The day after, conformity test was performed in three last groups using two mice in each group. The first group $(200 \mathrm{mg} / \mathrm{kg})$ showed no mortality. However, one mouse in group A $(800 \mathrm{mg} / \mathrm{kg})$ and both mice in group $1 / 2 \mathrm{~A}(400 \mathrm{mg} / \mathrm{kg})$ died during 24 hours of extract injection.

$\mathrm{LD}_{50}=\frac{(200+400)}{2}=300 \mathrm{mg} / \mathrm{kg}$

$200 \mathrm{mg} / \mathrm{kg}=$ Highest dose of test substance that gave no mortality,

$400 \mathrm{mg} / \mathrm{kg}=$ Lowest dose of test substance that gave mortality.

Based on results, the dose of Calligonum extract that kills $50 \%$ of the test animals will be $300 \mathrm{mg} / \mathrm{kg}$. According to acute toxicity classification table, it can be classified as moderately toxic agent. 


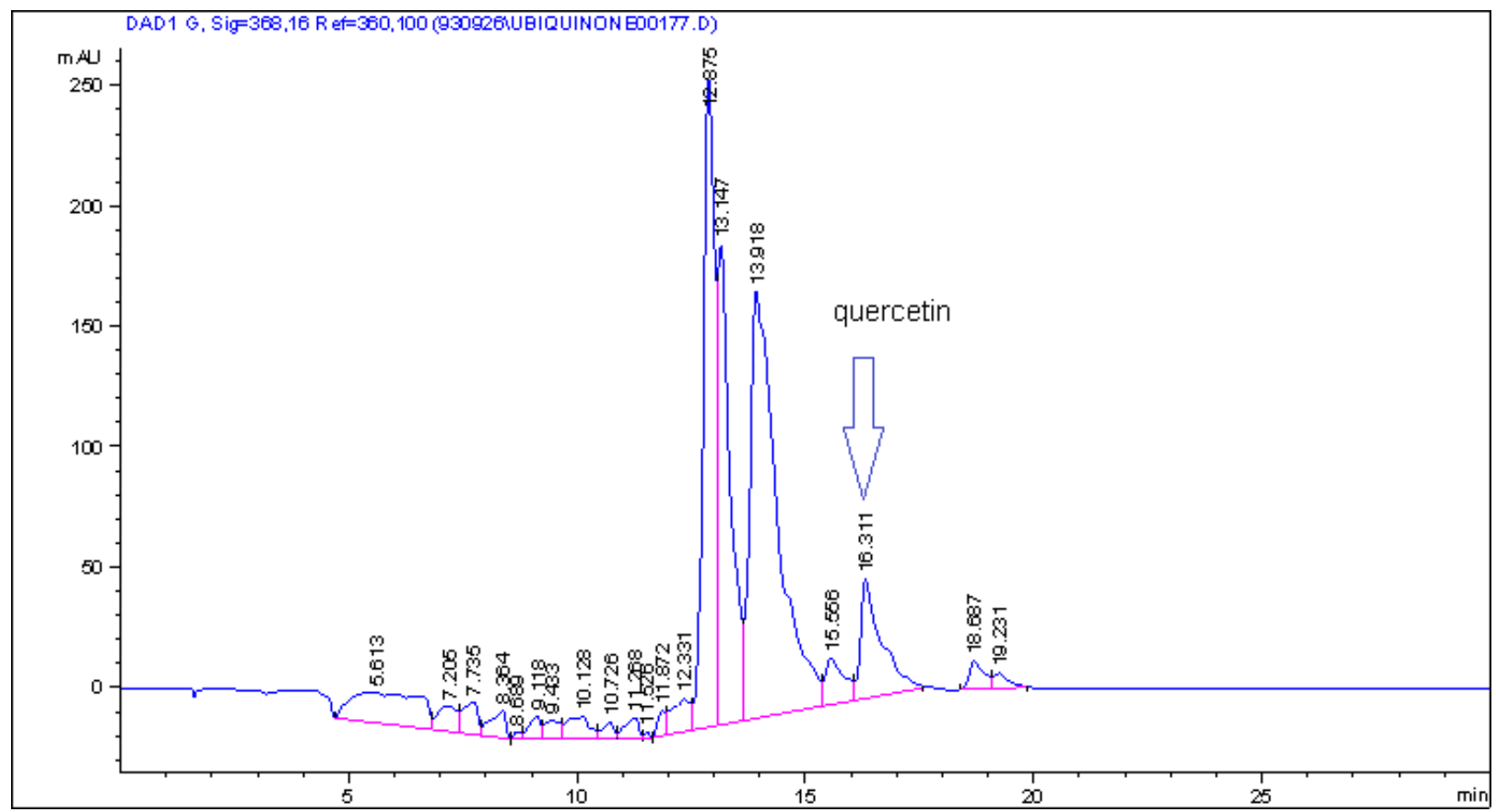

Figure 1:- Chromatogram of quercetin in fruit sample of Calligonumcomosum. Retention time of 16.31 min related to quercetin.

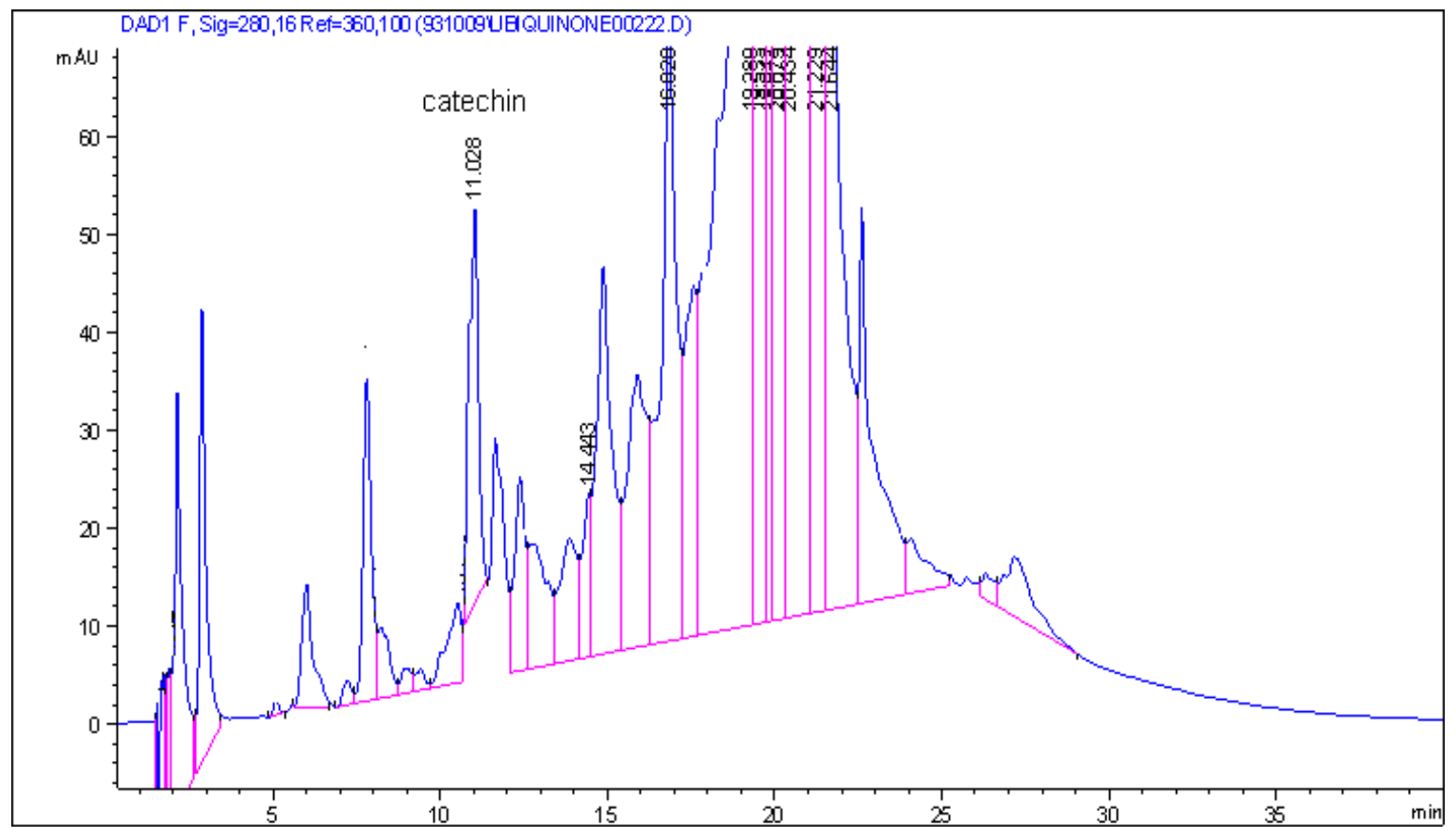

Figure 2:- Chromatogram of catechin in root sample of Calligonumcomosum. Retention time of 11.028 min related to catechin. 


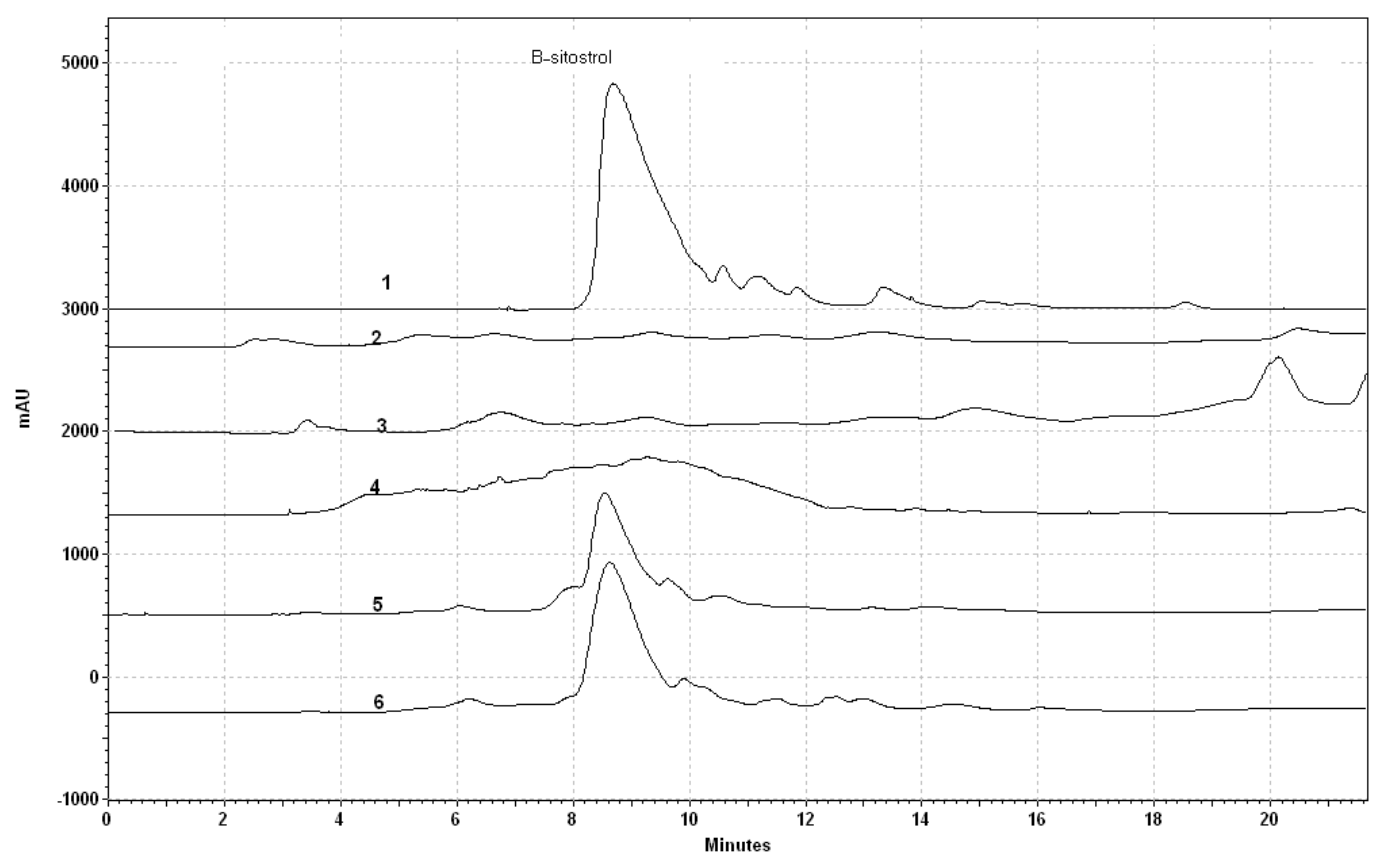

Figure3: Chromatogram of $\beta$-sitosterol in different parts of Calligonumcomosum. 1: Standard sample, 2: root sample, 3: stem sample, 4: fruit sample, 5: whole parts sample, 6: aerial part (leave and flowers) sample.

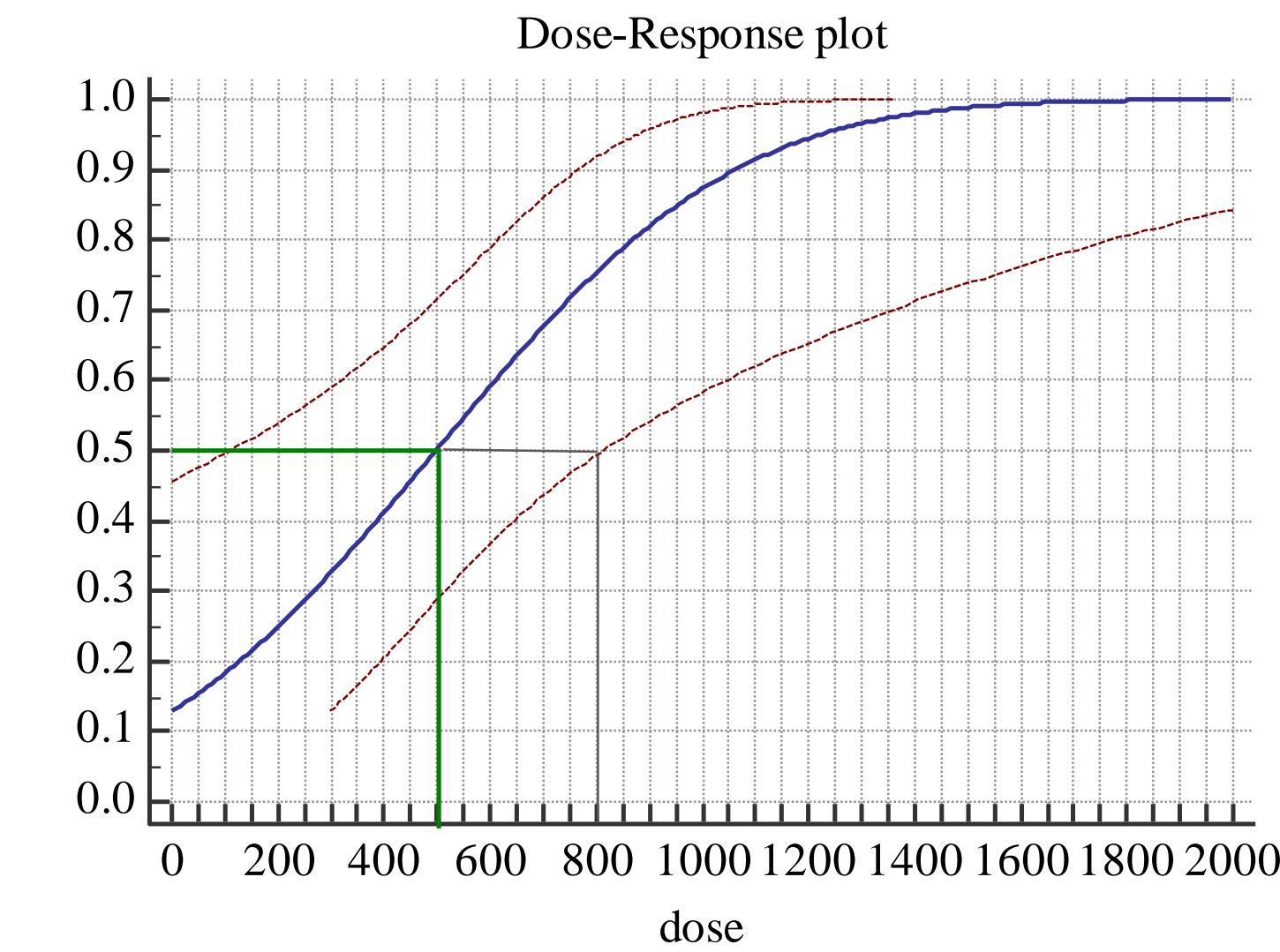

$\mathrm{LD}_{50}=497.9$

Lower 95\% Limit $=110.7$

Upper 95\% Limit $=813.2$

Figure 4:-Dose response plot and LD50 determination at in vivo acute toxicity assay of CalligonumComosum. 
Table 1:- Content of three compounds in five samples of C. comosum.

\begin{tabular}{|c|c|c|c|}
\hline Sample & $\begin{array}{c}\text { Quercetin } \\
(\mathbf{m g} / \mathbf{g})\end{array}$ & $\begin{array}{c}\text { Catechin } \\
(\mathbf{m g} / \mathbf{g})\end{array}$ & $\begin{array}{c}\boldsymbol{\beta} \text {-sitosterol } \\
(\mathbf{m g} / \mathbf{g})\end{array}$ \\
\hline fruit & $2 / 725 \pm 0.25$ & $1 / 279 \pm 0.35$ & $\mathrm{ND}$ \\
\hline stem & $0 / 009 \pm 0.03$ & $10 / 227 \pm 2.13$ & $0.66 \pm 0.0$ \\
\hline Whole parts & $2 / 1075 \pm 0.14$ & $1 / 722 \pm 0.03$ & $19.66 \pm 0.03$ \\
\hline root & $0 / 4285 \pm 0.07$ & $6 / 554 \pm 0.86$ & $11.33 \pm 0.09$ \\
\hline Calibration curve correlation coefficient(r) & $\mathrm{Y}=27.553 \mathrm{X}+71.59$ & $\mathrm{~N}=43 / 939 \pm 9.85$ & $\mathrm{ND}$ \\
\hline & $\mathrm{R}^{2}=0.9977$ & $\mathrm{R}^{2}=0.9994+19.987$ & $\mathrm{Y}=11170 \mathrm{X}+995$ \\
$\mathrm{R}^{2}=0.932$
\end{tabular}

Mean \pm SD $(\mathrm{n}=3)$

${ }^{\dagger}$ Not detected

Table 2:- IC50 values of DPPH radical scavenging effect of ethyl acetate fraction of five samples from C. comosum

\begin{tabular}{|c|c|}
\hline Sample & IC50 (mg/mL) \\
\hline Stem & 11.7 \\
\hline Fruit & 4.79 \\
\hline Aerial parts(leave and flower) & 2.9 \\
\hline Root & 3.95 \\
\hline
\end{tabular}

\section{Discussion:-}

In our knowledge, this is the first study that compared antioxidant and cytotoxic activity of different parts of Calligonumcomosum plant. The previous studies mainly assessed these potentials on a specific part of the plant such as aerial or fruit.

Selection of a proper part is very important when we aim to assess the therapeutic effect of a plant. Polyphenolic agents have many biological activities including antioxidative(Iraz, et al. 2006, Moon, et al. 2006), antiinflammatory (Park, et al. 2007), gastroprotective(Mojzis, Hviscova et al. 2001), cardioprotective(Zern, et al. 2005), and anticancer (Ren, et al. 2003) effects. In addition, we sometimes need lower toxic activity for prevention of side effects of a drug.

Our findings showed that three antioxidant agents including quercetin, catechin and $\beta$-sitostrol have variation in different parts of the plant. Quercetin had highest level in two parts (the aerial parts and fruit) of C. comusom. The roots showed highest amount of catechin and flowering branches demonstrated highest level of $\beta$-Sitostrol.

Badria et al. showed high antioxidant activity of aerial part (stem, flowers, and leaves) of the Calligonumcomosum. The best cytotoxic and antioxidant effect was related to dehydrodicatechinA agent(Badria, et al. 2007). At present study, we found the highest amount of catechin components in the root of the plant.

The toxicity effect of the plant was assessed by three different methods at present study. The brine-shrimp lethality bioassay test showed that the fruit extract with LC50 $126.8 \mu \mathrm{g} / \mathrm{mL}$ was more toxic than the other samples. However, MTT Results showed nontoxic effect of all samples on studied cell lines. The results of in vivo toxicity evaluation showed moderately toxicity of the chloroform-ethylacetate fraction of the aerial parts of the Calligonum extract. These findings can help clinicians for selection the best part with lowest side effect in future clinical trials.

\section{Acknowledgement:-}

This study is part of a Ph.D. dissertation at Tehran University of Medical Sciences, Tehran, Iran. This study was financially supported by Tehran University of Medical Sciences, Iran National Science Foundation. There is no conflict of interest in this study. 


\section{References:-}

1. Abdel-Sattar, E. A., S. M. Mouneir, G. F. Asaad and H. M. Abdallah (2014). "Protective effect of Calligonum comosum on haloperidol-induced oxidative stress in rat." Toxicol Ind Health30(2): 147-153.

2. Ali, R., Z. Mirza, G. M. Ashraf, M. A. Kamal, S. A. Ansari, G. A. Damanhouri, A. M. Abuzenadah, A. G. Chaudhary and I. A. Sheikh (2012). "New anticancer agents: recent developments in tumor therapy." Anticancer Res32(7): 2999-3005.

3. Alwakeel, S. (2008). "Microbial and heavy metals contamination of herbal medicines." Research Journal of Microbiology3(12): 683-691.

4. Badria, F. A., M. Ameen and M. R. Akl (2007). "Evaluation of cytotoxic compounds from calligonum comosum L. growing in Egypt." Z Naturforsch C62(9-10): 656-660.

5. Chinedu, E., D. Arome and F. S. Ameh (2013). "A new method for determining acute toxicity in animal models." Toxicology international20(3): 224.

6. Dashti, H., H. Azarnivand, H. Shirani, M. Hajabbasi and S. Maddahosseini (2011). "Response of three Calligonume species to salinity at germination and seedling stages." African Journal of Agricultural Research6(19): 4487-4493.

7. El-Hawary, Z. and T. Kholief (1990). "Biochemical studies on some hypoglycemic agents (II) effect ofCalligonum comosum extract." Archives of Pharmacal Research13(1): 113-116.

8. Finney, D. J. (1964). Probit Analysis: A Statistical Treatment of the Sigmoid Responce Curve, Cambridge University Press.

9. Ghazanfar, S. A. (1994). Handbook of Arabian medicinal plants, CRC press.

10. Hammami, R., I. Farhat, A. Zouhir and S. Fedhila (2011). "Detection and extraction of anti-Listerial compounds from Calligonum comosum, a medicinal plant from arid regions of Tunisia." Afr J Tradit Complement Altern Med8(3): 322-327.

11. Iraz, M., H. Erdogan, M. Kotuk, M. Yagmurca, T. Kilic, H. Ermis, E. Fadillioglu and Z. Yildirim (2006). "Ginkgo biloba inhibits bleomycin-induced lung fibrosis in rats." Pharmacol Res53(3): 310-316.

12. Kahkeshani, N., B. Farahanikia, P. Mahdaviani, A. Abdolghaffari, G. Hassanzadeh, M. Abdollahi and M. Khanavi (2013). "Antioxidant and burn healing potential of Galium odoratum extracts." Res Pharm Sci8(3): 197-203.

13. Khanavi, M., M. Nabavi, N. Sadati, M. Shams Ardekani, J. Sohrabipour, S. M. Nabavi, P. Ghaeli and S. N. Ostad (2010). "Cytotoxic activity of some marine brown algae against cancer cell lines." Biol Res43(1): 31-37.

14. Liu, X., M. Zakaria, M. Islam, R. Radhakrishnan, A. Ismail, H. Chen, K. Chan and A. Al-Attas (2001). "Antiinflammatory and anti-ulcer activity of Calligonum comosum in rats." Fitoterapia72(5): 487-491.

15. Masoum, S., H. Seifi and E. H. Ebrahimabadi (2013). "Characterization of volatile components in Calligonum comosum by coupling gas chromatography-mass spectrometry and mean field approach independent component analysis." Analytical Methods5(18): 4639-4647.

16. Mojzis, J., K. Hviscova, D. Germanova, D. Bukovicova and L. Mirossay (2001). "Protective effect of quercetin on ischemia/reperfusion-induced gastric mucosal injury in rats." Physiol Res50(5): 501-506.

17. Moon, H. K., E. S. Yang and J. W. Park (2006). "Protection of peroxynitrite-induced DNA damage by dietary antioxidants." Arch Pharm Res29(3): 213-217.

18. Park, H. H., S. Lee, J. M. Oh, M. S. Lee, K. H. Yoon, B. H. Park, J. W. Kim, H. Song and S. H. Kim (2007). "Anti-inflammatory activity of fisetin in human mast cells (HMC-1)." Pharmacol Res55(1): 31-37.

19. Pyankov, V. I., C. C. Black, E. G. Artyusheva, E. V. Voznesenskaya, M. S. Ku and G. E. Edwards (1999). "Features of photosynthesis in Haloxylon species of Chenopodiaceae that are dominant plants in Central Asian deserts." Plant and Cell Physiology40(2): 125-134.

20. Ranjbarfordoei, A., P. Vandamme and R. Samson (2013). "Some ecophysiological characteristics of artà (Calligonum comosum L' Hérit) in response to drought stress." Forest science and Practice15(2): 114-120.

21. Ren, W., Z. Qiao, H. Wang, L. Zhu and L. Zhang (2003). "Flavonoids: promising anticancer agents." Med Res Rev23(4): 519-534.

22. Taia, W. K. and M. O. El-Etaby (2006). "Taxonomical study in the desert plant Calligonum comosum L'Her from two different locations in Saudi Arabia." Asian J Plant Sci5(4): 570-579.

23. Zern, T. L., R. J. Wood, C. Greene, K. L. West, Y. Liu, D. Aggarwal, N. S. Shachter and M. L. Fernandez (2005). "Grape polyphenols exert a cardioprotective effect in pre- and postmenopausal women by lowering plasma lipids and reducing oxidative stress." J Nutr135(8): 1911-1917. 